прочесі діяльності підприємства, для оцінювання ризику, який випливає з конкретної небезпеки, $і$ для запровадження заходів по зниженню ймовірності виникнення небезпек.

На підприємствах зернопереробної галузі ідентифікація небезпек полягає у визначенні всіх об'єктів, ситуацій або дій (чи їх поєднання), щуо притаманні діяльності підприємства та несуть потенційну загрозу здоров 'ю та життю працівників. Одночасно розглядають різні види робіт і ситуацій, щзоб виявити небезпеки, які постійно присутні за нормальних умов роботи, а також небезпеки, вплив яких можливий за відхилення від нормальних умов роботи та аварійних ситуацій. Наведені приклади можливих небезпечних чинників на таких підприсмствах.

За результатами оцінювання ризиків визначають адекватність наявних заходів безпеки, потребу в їх поліпшенні чи запровадженні інших заходів безпеки.

Ключові слова: охорона праці, система управління охороною праці, ризик-орієнтований підхід, ідентифікація небезпек, виробничий ризик.

\title{
ЛІТЕРАТУР
}

1. Електронний ресурс. Режим доступу: http://uga.ua/calendar/forum-zernopererobnikiv-2018/.

2. Електронний ресурс. Режим доступу: https://dnaop.com/html/34112/doc$\% D 0 \% 94 \% D 0 \% A 1 \% D 0 \% A 2 \% D 0 \% A 3$ OHSAS 180012010.

3. Електронний ресурс. Режим доступy: https://zakon.rada.gov.ua/laws/show/989-2018-\%D1\%80/card3\#Files .

4. Електронний ресурс. Режим достуnу: https://zakon.rada.gov.ua/laws/show/994 b23 . Директива № 89/391/CEC Paди щьоо запровадження заходів заохочення поліпшення безпеки та охорони здоров\&\#39;я прачівників на роботі.

5. Електронний ресурс. Режим доступу: https://zakon.rada.gov.ua/laws/show/994 062 . Свропейська соиіальна хартія (переглянута). Страсбург, 3.05.1996 p.

6. ДСТУ ISO 31000:2018 «Керування ризиками. Керівні вказівки (ISO 31000:2018, IDT)». - К.: 2006. - 17 c.

7. Електронний ресурс. Режим доступy: https:// zakon3.rada.gov.ua/laws/show/ru/z0397-15/. Положення про системy управління охороною праці на підприємствах електроенергетики від 09.02.2015.

Надійшла 14.02.2019. Рецензія 19.02.2019.

До друку 22.02.2019.

Адреса для переписки:

вул. Канатна, 112, м. Одеса, 65039

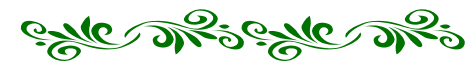

A. P. BOCHKOVSKYI ${ }^{1}$, PhD, ass. professor, N. Yu. SAPOZHNIKOVA ${ }^{2}$, PhD, senior lecturer ${ }^{1}$ Odessa National Polytechnic University, Odessa, Ukraine ${ }^{2}$ Odessa National Academy of Food Technologies, Odessa, Ukraine Ukraine

\section{ASPECT OF MINIMIZATION AREAS OF «HUMAN FACTOR》 IN LABOR SAFETY}

Abstrakt

The article analyzes well-known semantic interpretations of the term "human factor" in the context of the evolutionary development of the safety component in "man-machine-environment" systems. It has been ascertained that single, recognized by law term "human factor" still does not exists, but the majority of researchers attribute this phenomenon to the human psycho-physiological reaction to changes in the environment.

It is noted that this approach is erroneous because the manifestations of "human factor" at the individual level of each person should be considered in the context of the features of its three main components - biological, social and informational. The trends of the evolutionary development of the technosphere and the analysis of statistical data on occupational accidents, as well as industrial breakdowns and disasters, prove the need to introduce positive changes at the level of the "human factor" components. First of all, it concerns the information component, as the development of technologies over the past decade is far ahead of the level of training in the field of occupational safety, which does not allow maintaining the required level of occupational safety and labor culture in the conditions of a new range of previously unknown hazardous and harmful production factors.

It was emphasized that necessary positive changes in the components of the "human factor" should be implemented as a part of the concept of sustainable humanity development, which provides for the development of three interrelated areas: economic, social and spiritual growth of society. Thus, basic directions that will minimize the negative effects of the "human factor" within functioning of the future complex systems "man-machine-environment", are to increase the level of motivation for safe human behavior at production facilities and to form safety priorities over economic outcomes of enterprise's activity. The possibility to implement such directions directly depends on the implementation of the relevant reforms in the system of secondary, vocational and higher education, as well as occupational safety and industrial safety regulatory framework in Ukraine.

Keywords: labour safety, human factor, sustainable development, "man-machine-environment" systems, industrial safety. 
The last centuries of human development are characterized by the dynamic growth of the world's population, its business activity and, as a result, the creation of a huge technogenic space. During this time, the Earth's ecosystem has suffered great losses, that is, subject to degradation. It is sufficient to say that every hour the population of species on the Earth is reduced by two species, the fertile layer of the lithosphere is destroyed at the same pace and at the end of the twentieth century its loss amounted to over 500 billion tons. Air contamination during this period has increased thousand fold. Today, the dynamics of anthropogenic factors influence on the planet's ecosystem is confirmed by the historical statement of J.B. Lamarck: "Sometimes it seems that the purpose of a human being is to destroy his race, having previously made the globe unfit for life."

The trends that have emerged in the last hundred years, as well as the indisputable desire of a man to meet his ever-increasing needs, cast doubt on the existing model of human development. Back in the 80's, the United Nations Environment Program called for the transition to "development without destroying". At that time, for the first time, the concept of sustainable development in the World Conservation Strategy, developed on the initiative of the UN, the International Union for Conservation of Nature (IUCN) and the World Wildlife Fund, was widely publicized. In the report "Our Common Future", the World Commission on Environment and Development (WCED) focused on the need for "sustainable development," in which "meeting the needs of the present without compromising the ability of future generations to meet their own needs." This strategy was developed in the early 90's at the United Nations Conference in Rio de Janeiro, at the United Nations Climate Conference in Copenhagen and at the beginning of the 2000s at the World Summit on Sustainable Development in Johannesburg, where two important documents were adopted: Johannesburg Declaration on Sustainable Development and the Plan of Implementation of the World Summit on Sustainable Development [1 - 5].

The basis of the sustainable development model is the idea of "green" development of man-made environment, increase of safety level and quality of life while supporting diversity of the biosphere. In the mechanism of implementation of this idea, the central place is occupied by a human being, as the creator of the technosphere and the biosphere consumer.

The objective of this paper is the aspect of the human factor and its components as an object and subject of research.

It is supposed that this objective will be achieved in performance of the following tasks:

- evolution of the human factor and analysis of its components;

- trends in technogenic human activity;

- role of the human factor in technogenic activities;

- aspect of the human factor in sustainable development of mankind.

The evolutionary development of mankind involves continuous intensification of the technosphere formation processes, its technical re-equipment and changes in human labor activity conditions. The conse- quence of these processes is the growing dependence of technical, organizational and economic aspects of production activity and the technosphere in general on "human (subjective) factor".

One of the first attempts to reveal the meaning of the term "human factor" was made by the Soviet scientist N.M. Dobrotvorsky This term is an abbreviated translation of the "human factors engineering», which was used in the United States to refer to both the area of knowledge and the process of design of "man- machine" system. In the Soviet Union and in European countries, this term was used to refer mainly to the special area of knowledge - ergonomics [4 - 6].

The meaning of the term "human factor" has so far not been clearly defined and has not been unambiguously fixed in any regulatory document as a single term. Most researchers agree that the term should mean conscious or random erroneous human actions that are caused by the peculiarities of his biological nature and the conditions of interaction with the environment.

The ambiguity in the definition of this term makes it possible for experts and scientists to apply it to various fields of science: psychology, economics, medicine, life safety, labor safety, engineering, and others.

In the studies relating to health and labor safety, "human factor" is mainly considered as a function of the psycho-physiological state of a person, which mental regulation of the employee behavior depends on, which disorganization causes the pre-conditions of an injuryrisk situation. However, it is not entirely correct to interpret and consider this term only from the point of view of the function of psychophysiological state. Man as the unity of three main components - biological, social and psychological - exists in the modern society, where information plays a very important role. Hence, the term "human factor" is a multi-tier concept that should be considered, in our opinion, as a set of psycho-emotional, social, biological and informational components [5 - 8].

"Human factor", as an essential feature of each individual, is formed from biological stage (phenotype) and continues its formation during development and human life and activities in the society (problems of family, education, moral, cultural values, physical education, etc.).

Therefore, the lack of the necessary educational level, incompliance of the man's psychophysiological features with the conditions and nature of work being performed, as well as the low level of education and informational support leads to erroneous actions by employee at all stages - from development and design to management and operation of technosphere by the objects.

The history of the evolution of the mankind has undergone certain stages of its development from farming to industrial revolution, scientific and technological advance and development of information technologies. It is as a result of industrial revolution that the "bourgeoisie, as noted by K. Marx and F. Engels, has, in less than hundred years of class rule, created more numerous and more grandiose productive forces than all previous generations put together" $[3,9]$. Quick development of the technosphere at that time was determined by low level performance, high level of the environment pollution and 
neglect of labor safety.

Already in the XIX century, many species of animals and birds were exterminated completely or brought to the brink of extinction. Forests have been cut down in huge areas, which resulted in climate change, river shallowing, soil erosion and water pollution. The First World War, and then global economic crisis - "Great Depression" - which lasted until the end of the Second World War, became a catalyst for a new rapid development of the technosphere - scientific and technological advance. The growth of industrial production and the absurd use of natural resources led to the emergence of energy and commodity crisis, lack of fresh water and dangerous pollution of lytho-, hydro- and atmosphere. Today, these processes have become global and have got the common name of the environmental crisis. All stages of technogenic human activities were accompanied by different tendencies, which had undergone certain changes, but their fundamental factor has remained the same "human factor".

The role of the "human factor" at the present stage becomes more relevant in the context of the economic recovery in the world, when management at different levels puts the task to raise economic performance to pre-crisis level in a very short period and often in any possible way, which inevitably leads to an increase of errors, growth of injury-risk situations and man-made accidents.

Rapid improvement of machinery, accumulation of the information advance increasing demands for retraining of workers and engineering staff. By experts estimates, the period within which a half of the workers' knowledge becomes obsolete was reduced to 3-5 years $[3,5,8]$. That is, in most cases, rapid development of technosphere anticipates in a considerable way the level of training, skills, qualification of workers, and the level of social standards for working conditions, which eventually results to the preconditions of erroneous actions and injury-risk situations. Constant increase in the consumption of non-renewable material resources, complication of production processes, "cheapening" of products using environmentally hazardous technologies and materials, as well as unqualified use of automated (computer) control systems for these processes are the cause of anthropogenic accidents, which in their turn provoke natural disasters of destructive scale [7, 10, 11].

The existing model of human development is, in essence, a model for technosphere development "at any cost", in the center of which there is a man - main consumer of non-renewable natural resources and creator of technosphere. The key link between a man and a technosphere is the "human factor" (error), through which there is an anthropogenic impact, and as a consequence a degradation of the natural environment. The importance of the role of the "human factor" in anthropogenic human activity is evidenced by the studies of a world-class specialist, Bruce Steele, managing director of the consulting firm SMC (UK), that more than $99 \%$ of occupational injuries are related to the "human factor" [4 - 7].

Confirmation of these studies is data of the Institute of Mechanical Engineering of A.A Blagonravov RAS, which are given in the fig. 1 in the form of values

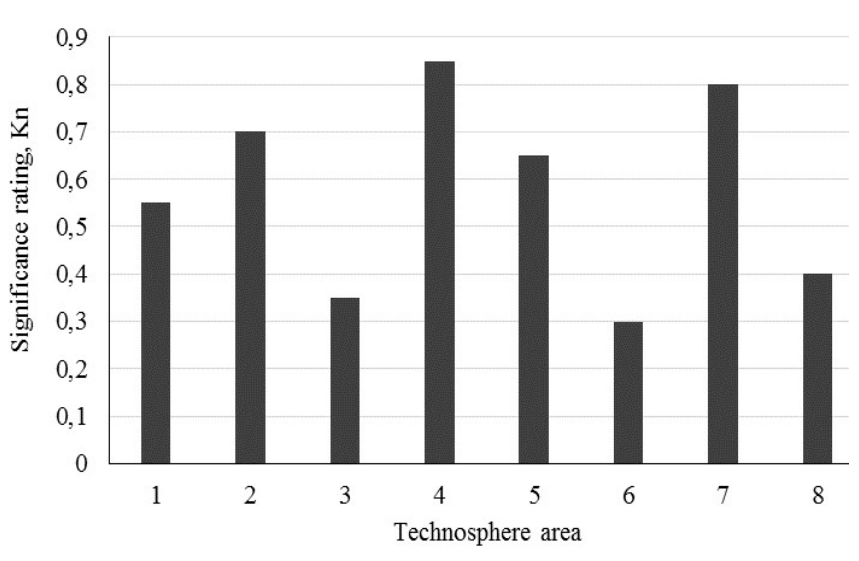

Fig. 1 - Significance rating of the "human factor", $K_{n}$, in man-made disasters in some areas of the technosphere: 1 - atomic energy; 2 - indistrial and civil construction; 3 - rocket and space technology; 4 - military aviation; 5 - civil aviation; 6 - pipeline transport; 7 - motor transport; 8 - process equipment

of the coefficient of significance of the "human factor", $\mathbf{K}_{\mathbf{n}}$ in man-made disasters [4].

As is obvious from the figure 1 , the significance rating $\boldsymbol{K}_{\boldsymbol{n}}$ is quite important in man-made disasters for the most important sectors of the technosphere. Therefore, the existing model of the mankind development, may be recognized deadlock.

To take as a basis as early as possible the concept of "sustainable development" of humanity, the essence of which is the "green" development of the technosphere and increase in safety level of technology and labor will allow, in our opinion, to implement the long-overdue process of transition from the existing model to a new one, which shall take the humanity to a fundamentally new future-proof and harmonious level of development. Confirmation of this opinion is the quote from the latest ILO report devoted to the World Day for Safety and Health at Work: "Everybody recognizes the growing costs of energy-intensive production and consumption patterns. It is the right time to shift to the economy that provides high employment rate and low emissions. Green work places promise triple benefits - the development of viable enterprises, poverty reduction and restoration of employment-oriented economy"'[12].

At the first stage of transition to a new (futureproof) development model, it is necessary to reduce gradually inefficient use of non-renewable environmental resources and increase proportionally the introduction of advanced technologies that enable the use of so-called "green" energy for the technosphere needs. It is difficult to implement it in the world of growing competition and rather high costs for implementation of environmentally friendly technologies, but the interest of certain technosphere areas to get tax, social and other benefits from the state is able to give a powerful stimulus to the process of implementation of "green" technologies. At the same time, the trends in transition to "informational society" - intangible flows economy: finance, information, images, messages, communications, intellectual property, which gradually leads to the so-called "dematerialization" of economic activity. According to statistical data, already nowadays, the volume of financial transac- 
tions exceeds the volume of trade in material goods by 8,5 times [5]. The driving force of the new economy will be not only the shortage of non-renewable natural resources, but also the development of information resources and knowledge.

The concept of "sustainable development" is based on the unity of three main components: economic, environmental and social. A man plays the main role in harmonious management of these components.

According to ILO estimates, the transition to a "green" economy is able to generate from 15 to 60 million additional jobs. About 1.0 billion of employees will be affected by the transition to a more environmentally friendly system $[5,9]$. However, the technologies that are able to protect the environment may be hazardous in terms of occupational safety, since the creation of new jobs and the use of new technologies and materials require a certain level of knowledge, skills and qualifications from personnel. Involving a substantial number of new employees to the transition process to a new model of development requires solving the following problems:

- the first problem is that, along with wellknown hazardous and harmful factors, new ones may arise, which protection requires a new level of knowledge and technologies, especially in matters of occupational safety;

- the second problem that arises in implementing a future-proof model of development, is in the "human factor" as in the existing model that is this factor does not disappear anywhere, but remains a key one.

Therefore, the main goal to be achieved in solving these problems is to reduce the "human factor" effect, which in turn will lead to maximization of the right decision-making by the technosphere experts and minimization of errors. It s possible to achieve this objective only by fundamental reinterpretation of all the components of the "human factor". The first step in the reinterpretation process should be comprehensive increase of education- al, cultural and formative levels of a man - first of all, in the field of occupational and environmental safety. Starting from the school curriculum, it is necessary to continuously improve them, at all stages of professional and career growth of the individual, relying on and quickly responding to the trends and dynamics of changes in all the factors of the concept of "sustainable development". Gradual implementation of this process at all stages of human development will form an individual, and ultimately, public consciousness. The outcome of this activity should be a personality who builds his relationship with the environment on the basis of understanding of his integrity, that is, on the principles of humanism.

The studies carried out allow to draw the following conclusions:

1. The term "human factor", its content and components were transformed in the process of evolutionary development of the mankind.

2. The trends in development of technogenic human activity have shown that the existing model of development is a deadlock. The way out is the transition to a new (perspective) development model.

3. The key link between a human being and technosphere in the existing model of development is the "human factor" (error) itself, through which there is a technogenic impact, and as a consequence, degradation of the natural environment.

4. To reduce the "human factor" effect is possible only by fundamental reinterpretation of all its components and comprehensive enhancement of educational, cultural and educational levels of the technosphere specialists - first of all in matters of labor protection and environment.

5. The model of sustainable development of mankind is not ideal, since in its implementation a "human factor" remains a key factor. The main objective to be achieved in implementing an advance model is to reduce the impact of this factor.

\section{REFERENCES}

1. Rutkevich M.N. Filosofskoe znachenie kontseptsii ustoychivoho razvitiya // Voprosy filosofii . 2002. T. 1, vyp. 11. S. 26-28.

2. Likhtenshteyn V.E., Ross H.V. Portal studencheskikh i nauchnykh materialov // vvedenie v teoriyu razvitiya. 2005. URL: https://ozlib.com/828920/ekonomika/vvedenie_v_teoriyu_razvitiya(data obrashcheniya: 01.02.2019).

3. Yokhannesburhskaya deklaratsiya po ustoychivomu razvitiyu. Doklad Vsemirnoy vstrechi na vysshem urovne po ustoychivomu razvitiyu // Elektronnyy fond pravovoy i normativno-tekhnicheskoy dokumentatsii : [Veb-sayt]. 2004. URL: http://docs.cntd.ru/document/901893000 (data obrashcheniya: 01.02.2019).

4. Bochkovs'kiy A.P. «Lyuds'kiy faktor» ta profesiyniy rizik: vipadkovist' chi zakonomirnist' // Zernovi produkti $i$ kombikormi. 2014. T. 4, vip. 54. S. 7-13.

5. Netrebs `kiy O.A., Bochkovs `kiy A.P. Aktualizatsiya «lyuds `koho faktora» u stalomu rozvitku lyudstva // Kharchova nauka $i$ tekhnolohiya. 2012. T. 4, vip. 21. S. 100-103.

6. Dobroborskiy B.S. Bezopasnost' mashin i chelovecheskiy faktor: monohrafiya. SPb: HASU, 2011. $112 \mathrm{~s}$.

7. Bochkov' kiy A.P. Prioritetni napryamki udoskonalennya sistemi upravlinnya okhoronoyu pratsi na pidpriyemstvakh // Zernovi produkti i kombikormi. 2014. T. 2, vip. 54. S. 11-16.

8. Bochkovskyi A., Sapozhnikova N. Promising directions for improving regulatory legal framework of Ukraine on labor protection for enterprises producing food and beverage // Ekolohichna bezpeka ta zbalansovane resursokoristuvannya. 2015. Vol. 2, No. 12. P. 85-93.

9. Marks K., Enhel's F. Sochineniya: sobranie sochineniy. M: Hosudarstvennoe izdatel stvo politicheskoy literatury, 1955. T. 4. S. 419-459.

10. Bochkovs 'kiy A. Sapozhnikova N. Formalizatsiya sistemi avtomatizovanoho kontrolyu i pidvishchennya bezpeki virobnitstv // Visnik L vivs koho derzhavnoho universitetu bezpeki zhittyediyal nosti. 2017. Vip. 15. S. 114-123.

11. Bochkovs'kiy A.P., Sapozhnikova N.yu. Naukovo - praktichni aspekti minimizatsiyi rizikiv viniknennya profesiynikh nebezpek // Ekolohichna bezpeka ta zbalansovane resursokoristuvannya. 2017. T. 2, vip. 16. S. 92-101.

12. International Labour Organization: [Veb-sayt]. Switzerland, 2005. URL: https://www.ilo.org/global/publications/lang-en/index.htm (data zvernennya: 01.02.2019). 
А.П. БОЧКОВСБКИЙ ${ }^{1}$, канд. техн. наук, доцент Н.Ю. САПОЖНІКОВАㄹ, канд. техн. наук, ст.викладач ${ }^{1}$ Одеський національний політехнічний університет, Одеса ${ }^{2}$ Одеська національна академія харчових технологій, Одеса

\title{
АСПЕКТАЦІЯ НАПРЯМІВ МІНІМІЗАЦІЇ «ЛЮДСЬКОГО ФАКТОРА» В ОХОРОНІ ПРАЦІ
}

\begin{abstract}
Анотація
В статті проаналізовані відомі смислові інтерпретації терміну «людський фактор» в контексті еволючійного розвитку безпекової складової систем «людина-машина-середовище». Встановлено, щзо єдиного, закріпленого на законодавчому рівні, терміну «людський фактор» поки щь не існує, але більшість дослідників пов'язують дане явище з психофізіологічною реакиією людини на зміни оточуючого середовища.

Зазначено, щэо такий підхід є помилковим оскільки прояви «людського фактора» на індивідуальному рівні кожної людини слід розглядати в контексті особливостей їі трьох основних складових - біологічної, соціальної та інформаційної. Тенденції еволючійного розвитку техносфери та аналіз статистичних даних щуодо нещасних випадків пов'язаних з виробництвом, а також промислових аварій та катастроф, свідчать про необхідність впровадження позитивних змін на рівні визначення складових «людського фактора». В першу чергу, ие стосується інформаційноі складової, оскільки розвиток технологій за останні десятиліття значно випереджає рівень освіти прачівників в галузі охорони праці, який не дозволяє підтримувати необхідний рівень професійної безпеки $і$ культури праці в умовах існування нової номенклатури раніше не відомих небезпечних та шкідливих виробничих факторів.

Підкреслено, щзо необхідні позитивні зміни складових «людського фактора» потрібно впроваджувати в рамках концепиії сталого розвитку людства, яка передбачає розвиток за трьома взаємопов'язаними напрямками: економічне, соиіальне та духовне зростання суспільства. Отже основними напрямками, що дозволять мінімізувати негативні прояви «людського фактора» в рамках функиіонування майбутніх складних систем «людина-машинасередовище», є підвищення рівня мотивації безпечної поведінки людини в умовах виробництва та формування пріоритетів безпеки над економічними результатами діяльності підприємств. Можливість реалізації зазначених напрямків напряму залежить від впровадження відповідних реформ систем середньої, професійно-технічної та вищоі освіти, а також нормативно-правової бази Украйни з охорони праці та промислової безпеки.
\end{abstract}

Ключові слова: охорона праці, людський фактор, сталий розвиток, системи «людина-машина-середовище», промислова безпека.

\section{ЛІТЕРАТУРА}

1. Руткевич М.Н. Философское значение концеепции устойчивого развития // Вопросы философии. 2002. T. 1, вып. 11. C. 26-28.

2. Лихтенштейн В.Е., Росс Г.В. Портал студенческих и научных материалов // введение в теорию развития. 2005. URL: https://ozlib.com/828920/ekonomika/vvedenie_v_teoriyu_razvitiya(дата обращения: 01.02.2019).

3. Йоханнесбургская декларация по устойчивому развитию. Доклад Всемирной встречи на высшем уровне по устойчивому развитию // Электронный фонд правовой и нормативно-технической документачии: [Веб-сайт]. 2004. URL: http://docs.cntd.ru/document/901893000 (дama обрашения: 01.02.2019). Transliteration: Yokhannesburhskaya deklaratsiya po ustoychivomu razvitiyu. Doklad Vsemirnoy vstrechi na vysshem urovne po ustoychivomu razvitiyu // Elektronnyy fond pravovoy i normativno-tekhnicheskoy dokumentatsii: [Veb-sayt]. 2004. URL: http://docs.cntd.ru/document/901893000 (data obrashcheniya: 01.02.2019).

4. Бочковський А.П. «Людський фактор» та професійний ризик: випадковість чи закономірність // Зернові продукти і комбікорми. 2014. T. 4, вип. 54. C. 7-13.

5. Нетребський О.А., Бочковський А.П. Актуалізація «людського фактора» у сталому розвитку людства // Харчова наука і технологія. 2012. T. 4, вип. 21. С. 100-103.

6. Доброборский Б.С. Безопасность машин и человеческий фактор: монография. СПб: ГАСУ, 2011. $112 \mathrm{c}$.

7. Бочковський А.П. Пріоритетні напрямки удосконалення системи управління охороною праці на підприємствах // Зернові продукти і комбікорми. 2014. Т. 2, вип. 54. С. 11-16.

8. Bochkovskyi A., Sapozhnikova N. Promising directions for improving regulatory legal framework of Ukraine on labor protection for enterprises producing food and beverage // Екологічна безпека та збалансоване ресурсокористування. 2015. Vol. 2, No. 12. P. 85-93.

9. Маркс К., Энгельс Ф. Сочинения: собрание сочинений. М: Государственное издательство политической литераmуры, 1955. T. 4. C 419- 459.

10. Бочковський А.П., Сапожнікова Н.Ю. Формалізація системи автоматизованого контролю і підвищення безпеки виробництв // Вісник Львівського державного університету безпеки життєдіяльності. 2017. Вип. 15. C. 114-123.

11. Бочковський А.П., Сапожнікова Н.Ю. Науково - практичні аспекти мінімізаиї ризиків виникнення професійних небезпек // Екологічна безпека та збалансоване ресурсокористування. 2017. T. 2, вип. 16. С. 92-101.

12. International Labour Organization: [Bеб-caŭm]. Switzerland, 2005. URL: https://www.ilo.org/global/publications/lang-en/index.htm(дата звернення: 01.02.2019).

Надійшла 04.02.2019. Рецензія 09.02.2019. 